e-Journal Al-Syakhsiyyah: Journal of Law \& Family Studies, Vol. 2 No.1 (2020)

(C) Fakultas Syariah IAIN Ponorogo (2020)

Published Online ; Juni 2020

MENUJU FIQIH PROGRESIF

(Fiqih Modern Berdasarkan Maqashid Al Syariah Perspektif Jaser Auda)

\title{
TEGUH ANSHORI
}

Fakultas Syari' ah IAIN Ponorogo

myteguhanshori@gmail.com

ABSTRAK : Penelitian ini berangkat dari sebuah stigma bahwa Islam dianggap menjadi agama yang kaku dan sebagian orang melabeli Islam sebagai agama garis keras, agama yang statis, agama yang normatif dan tradisional. Mengingat kompleksitas permasalahan Islam yang semakin komplek, perlu adanya rekonstruksi dan reaktualisasi Fiqih atau Hukum Islam yang bersifat abstak dan kaku menjadi Fiqih atau Hukum Islam yang bersifat konkrit dan luwes. Salah satunya adalah tawaran Jaser Auda dalam konsep Maqashid al Syari'ah dalam hukum Islam atau fikih. Jasser Auda mencoba mengkonstruk ulang konsep Maqashid Al Syariah lama yang bersifat protection and preservation menuju pada teori maqashid al syariah yang bersifat pada development and rights. Pendekatan Maqashid Al Syariah adalah pendekatan teori fiqih yang bersifat holistic (Kulliyun) dan tidak membatasi pada teks ataupun hukum parsialnya. Namun lebih mengacu pada prinsip-prinsip tujuan universal. Dalam kajian Maqashid Al Syari'ah, pendekatan sistem dilakukan melalui beberapa langkah, yaitu, Pertama, Memvalidkan semua pengetahuan (multi pendekatan/ilmu). Kedua, Menggunakan Prinsip-prinsip Holistik. Ketiga, Keberanian membuka diri dan melakukan pembaharuan. Keempat, Mengukur qat'i dan ta'arud dari sisi ketersediaan bukti pendukung dan penentuan skala prioritas berdasarkan kondisi sosial yang ada dan bukan dari verbalitas teks. Kelima, Menggunakan pertimbangan Maqashid sebagai pendekatan penetapan Fiqih atau Hukum Islam. Pendekatan Maqashid Al Syari'ah hendaknya dijadikan sebagai tujuan pokok dari semua dasar metodologi linguistik dan rasional dalam Ijtihad, terlepas dari berbagai varian metode dan pendekatanya. Karena, merealisasikan Maqashid Al Syari'ah sebagai sistem, pendekatanya akan dapat mencapai keterbukaan, Pembaharuan, realistis dan fleksibel dalam sistem Hukum Islam atau Fiqih.

\section{Kata kunci: Jaser Auda, Maqasid Al Syariah, Pendekatan Sistem.}

ABSTRACT : This research called from a stigma that Islam is considered to be a rigid religion and some people label Islam as a hard-line religion, a static religion, a normative and traditional religion. Given the increasingly complex complexity of Islamic issues, the need for reconstruction and actualization of Fiqh or rigid and rigid Islamic Law becomes Figh or Islamic Law that is concrete and flexible. One of them is Jaser Auda's offer in the concept of Maqashid al Shari'ah in Islamic law or figh. Jasser Auda tries to reconstruct the old concept of Maqashid Al Sharia which is protection and preservation towards the theory of maqashid al sharia which is on development 
and rights. The Maqashid Al Syariah approach is a holistic theory approach (Kulliyun) and does not limit the text or its partial law. But rather refers to the principles of universal purpose. In the study of Maqashid Al Shari'ah, the system approach is carried out through several steps, namely, First, Validating all knowledge (multi approaches / sciences). Second, Using Holistic Principles. Third, Courage to open up and do the renewal. Fourth, Measuring qat'i and ta'arud in terms of the availability of supporting evidence and determining the scale of priorities based on existing social conditions and not from the verbality of the text. Fifth, use Maqashid consideration as an approach to determining Figh or Islamic Law. The Maqashid Al Shari'ah approach should be used as the main objective of all the basic linguistic and rational methodologies in Ijtihad, regardless of the various variants of methods and approaches. The realizing is Maqashid Al Shari'ah as a system, it is why the approach will be able to achieve openness, renewal, realistic and flexible in the system of Islamic Law or Figh.

Keywords: Jaser Auda, Maqasid Al Syariah, Systems Approach.

\section{PENDAHULUAN}

Fiqih merupakan salah satu bidang dari studi Islam yang paling dirasakan oleh masyarakat muslim, karena Fiqih bersentuhan langsung dengan kehidupan sehari-hari. Contoh Fiqih secara sempit tentang ajaran wudhu, shalat, puasa dan tata cara haji atau disebut fiqih Ibadah. Contoh Fiqih secara luas seperti tata cara jual beli, perdagangan, sewa menyewa dapat disebut Fiqih Muamalah.

Nabi Muhammad SAW merupakan aktor pelaksana Fiqih, karena Nabi Muhammad secara langsung mendapatkan wahyu dari Alloh SWT. Setelah Nabi Muhammad SAW wafat, hukum Islam mengalami stagnasi dan bersifat kekal. Fiqih menjadi statis dan tidak mampu menjawab persoalan yang semakin komplek. Dalam menjawab tantangan zaman Fiqih pada masa Rasul tentu kesulitan untuk menjawab masalah kontemporer seperti saat ini.

Kompleksitas masalah yang dihadapi umat Islam sekarang ini sangat berat, Islam dianggap menjadi agama yang kaku dan sebagian orang melabeli Islam sebagai agama garis keras, agama terorisme dan label-label yang menyudutkan Islam lainya. Yang menjadi pertanyaan substansinya adalah, kenapa konsep Maqashid Al Syariah dari Fiqih tidak berjalan?.

Perlu adanya rekonstruksi dan reaktualisasi Maqashid Al Syari'ah Fiqih Klasik yang bersifat abstak dan kaku menjadi Fiqih yang bersifat konkrit dan luwes, karena menjadi sesuatu yang lazim diketahui bahwa persoalan hukum yang muncul pada masa kini berbeda dengan persoalan hukum zaman lampau. Perbedaan tersebut dapat berupa materi hukum atau konteks hukumnya.

Supaya Islam menjadi agama yang sesuai dengan segala tempat dan masa, Substansi Maqashid Al Syari'ah dari Fiqih itu sendiri perlu digali ulang supaya dapat menjawab segala persoalan umat yang semakin komplek seperti saat ini. Salah satunya adalah tawaran Jaser Auda dalam konsep Maqashid Al Syari'ah dalam Fiqih. 


\section{Pengertian Hukum Islam, Syari'at dan Fiqih.}

Pengertian Hukum Islam sampai saat ini masih rancu dengan pengertian Syari'at dan Fiqih itu sendiri. Untuk itu pengertian Hukum Islam disini dibagi menjadi dua yaitu Hukum Islam dalam bentuk Syari'at dan Hukum Islam dalam Bentuk Fiqih. Artinya, pengertian ketiganya adalah sekelompok yang saling terkait tapi dapat di bedakan, yaitu ilmu yang berkaitan dengan amal perbuatan manusia yang diambil dari nash Al Qur'an atau As-Sunah yang berhubungan dengan amal perbuatan tersebut, atau yang diambil dari sumber-sumber lain. ${ }^{1}$

Imam Syafi'i mengartikan Syari'at adalah peraturan peraturan yang bersumber dari wahyu dan kesimpulan kesimpulan yang dapat dianalisis dari wahyu itu mengenai tingkah laku manusia. ${ }^{2}$ Dalam rumusan Imam Syafi'i tersebut terdapat dua hal yang disatukan, pertama, peraturanperaturan yang bersumber dari wahyu yang berarti syari'at, kedua, kesimpulan-kesimpulan yang dapat dianalisis dari wahyu itu yang berarti Fiqih. Sehingga dapat diartikan bahwa Hukum Syari'at adalah semua ketetapan hukum yang ditentukan langsung oleh Allah yang terdapat dalam Al Qur'an dan penjelasan nabi Muhammad dalam kedudukan beliau sebagai Rasullulah yang tertuang dalam kitab-kitab hadis. ${ }^{3}$

Fiqih dalam arti bahasa adalah paham atau pengertian, Hukum Fiqih adalah ketentuan-ketentuan hukum yang dihasilkan oleh ijtihad para ahli hukum Islam. Sedangkan Ilmu Fiqih adalah ilmu yang bertugas menentukan dan menguraikan norma-norma hukum dasar yang terdapat dalam $\mathrm{Al}$ Qur'an dan ketentuan-ketentuan umum yang terdapat dalam sunah nabi yang direkam dalam kitab-kitab hadis, dengan kata lain ilmu Fiqih berusaha memahami hukum-hukum yang terdapat dalam Al Qur'an dan Sunah Nabi Muhammad untuk diterapkan pada perbuatan manusia yang telah dewasa yang sehat akalnya yang berkewajiban melaksanakan hukum Islam. ${ }^{4}$

Dari pengertian dan istilah diatas dapat dipahami bahwa terminologi Hukum Islam memuat dua hal, yaitu Syari'at dan Fiqih, Keduanya dalam praktiknya masih sering dikonotasikan sama, baik dalam penyebutan istilah maupun dalam materi. Sebenarnya secara substansi keduanya memiliki garis pemisah tersendiri namun keduanya satu kesatuan yang tidak dapat dipisahkan. Dalam kepustakaan Hukum islam bahasa Inggris, Syari'at Islam diistilahkan Islamic Law, sedangkan Fiqih Islam disebut Islamic Jurisprudence. Dalam istilah Hukum Islam di Indonesia, Syari'at disebut Hukum Syari'at atau Hukum Syara', Sedangkan Fiqih disebut Hukum Fiqih. Syaria'at adalah landasan Fiqih, Fiqih adalah pemahaman tentang syari'at.

${ }^{1}$ Abuddin Nata, Metodologi Studi Islam, (Jakarta: PT RajaGafindo Persada, 2011) 298.

${ }^{2}$ Mohammad Daud Ali, Hukum Islam, pengantar ilmu hukum dan tata hukum Islam di Indonesia, (Jakarta: PT RajaGafindo Persada, 2011) 50.

3Ibid, hlm. 51

${ }^{4}$ Ibid, hlm. 48 
Al Qur'an secara tersurat menyebutkan Istilah Syari'at dan Fiqih. Istilah Syari'at tertuang dalam Surat Al Jaatsiyah ayat 18 :

"Kemudian Kami jadikan kamu berada di atas suatu syariat (peraturan) dari urusan (agama itu), Maka ikutilah syariat itu dan janganlah kamu ikuti hawa nafsu orang-orang yang tidak mengetahui". ${ }^{5}$

Sedangkan Istilaf Fiqih tertuang dalam Al Qur'an surat At Taubah ayat 122.

" Tidak sepatutnya bagi mukminin itu pergi semuanya (ke medan perang). mengapa tidak pergi dari tiap-tiap golongan di antara mereka beberapa orang untuk memperdalam pengetahuan mereka tentang agama dan untuk memberi peringatan kepada kaumnya apabila mereka telah kembali kepadanya, supaya mereka itu dapat menjaga dirinya". ${ }^{6}$

Ahli hukum atau yang disebut fuqaha mendefinisikan fiqih ke dalam dua sisi, yaitu Fiqih sebagai ilmu dan Fiqih sebagai hasil ilmu.Fiqih sebagai hasil ilmu ini disebut dengan kumpulan-kumpulan hukum-hukum syara'yang dihasilkan melalui ijtihad.Fiqih sebagai ilmu didefinisikan oleh Abu Zahrah dengan "Ilmu yang mengupayakan lahirnya hukum syara' amali dari dalil-dalil rinci" (satuan teks Al-Qur'an dan hadist). ${ }^{7}$ Pengertian ini mengandung tiga unsur, pertama, Sebagai Ilmu, Kedua, Unsur hukum syara', ketiga, unsur dalil-dalil rinci.

Fiqih sebagai Ilmu memiliki karakteristik sebagai berikut :

1. Dihasilkan dari akumulasi pengetahuan - pengetahuan yang tersusun melalui asas - asas tertentu.

2. Pengetahuan-pengetahuan tersebut terjaring dalam satu kesatuan sistem

3. Memiliki metode-metode tertentu.

\section{Perbedaan Antara Hukum Syari'at dan Hukum Fiqih}

Sebagai ahli hukum Islam harus dapat membedakan mana Hukum Islam yang disebut Syari'at dan Hukum Islam dalam arti Hukum Fiqih. Secara pokok perbedaan anatara keduanya adalah sebagai berikut. ${ }^{8}$ Pertama, dasar atau dalil yang digunakan, Syari'at didasarkan pada nash Al Qur'an dan As Sunah secara langsung tanpa menggunakan penalaran. Sedangkan Fiqih didasarkan pada dalil-dalil yang dibangun oleh ulama melalui penalaran atau ijtihad dengan tetap berpegang pada semangat dalam syari'at. Kedua, Syari'at bersifat kekal, permanen dan abadi. Sedangkan Fiqih bersifat temporer dan dapat dirubah.

Ketiga, Syari'at bersifat fundamental dan memilki ruang lingkup yang lebih luas (akidah dan Akhlaq), sedangkan Fiqih bersifat instrumental, ruang lingkupnya terbatas pada hukum yang mengatur perbuatan manusia, yang biasanya disebut sebagai perbuatan hukum. ${ }^{9}$

\footnotetext{
5 Al Qur'an digital

${ }^{6}$ Ibid, Al Qur'an digital

${ }^{7}$ Muhammad Abu Zahrah, Usul Al Figh, tanpa tahun, mesir dar al-fikr al-arabi

${ }^{8}$ Abuddin Nata, Op Cit. hlm 298-299.

${ }^{9}$ Mohammad Daud Ali, Op Cit, hlm. 51
} 
Keempat, Syari'at hanya satu, sedangkan Fiqih lebih dari satu seperti misalnya Fiqih empat Imam Mazhab. Kelima, Syari' at menunjukkan kesatuan dalam Islam, sedangkan Fiqih menunjukkan keragaman. ${ }^{10}$

Hukum Fiqih, sebagai hukum yang diterapkan dalam kasus tertentu dalam keadaan konkret akan mengalami perubahan dari masa ke masa dan berbeda dari satu tempat ketempat lain. Hal tersebut sesuai dengan kaidah Fiqih " perubahan tempat dan waktu menyebabkan perubahan hukum (Fiqih)", Artinya perubahan waktu dan tempat yang menyebabkan hukum Islam (Fiqih) dapat berubah, dalam sistem hukum Islam disebut Illat (latar belakang yang menyebabkan ada atau tidak adanya hukum atas sesuatu hal). ${ }^{11}$

\section{Urgensi Pendekatan Fiqih dalam Studi Islam}

Fiqih sebagai pendekatan berusaha menjadi sebuah ilmu yang berfungsi sebagai pisau analisis terhadap obyek yang ingin di dekati atau di bedah. Islam sebagai agama universal menjadi obyek penelitian yang tidak hanya di dekati dengan ilmu tunggal.

Pendekatan Fiqih sangat urgen dalam melakukan pendekatan dalam studi Islam, karena Fiqih bersentuhan langsung dengan hukum-hukum keseharian seorang Muslim. Dalam tataran realita, Hukum Islam atau Fiqih sering terjadi perdebatan dan perbedaan, terjadinya perbedaan dan perdebatan tersebut menjadi sesuatu yang wajar karena Fiqih adalah hasil ijtihad para Fuqaha. Pendekatan Fiqih dapat dibagi menjadi dua hal.

1. Pendekatan Fiqih Secara Etimologi

Pendekatan Fiqih berasal dari dua suku kata, Pendekatan dan Fiqih, kedua kata tersebut tentu memiliki pengertisn berbeda.

a. Pendekatan berasal dari kata dasar "Dekat", yang berarti tidak jauh, pendek. Kemudian diberi imbuhan pe- di awal dan akhiran-an yang dapat diartikan cara atau aktivitas untuk mendapatkan sesuatu. ${ }^{12}$

b. Pendekatan menurut Kamus Besar Bahasa Indonesia adalah proses, cara, perbuatan mendekati (hendak berdamai, bersahabat) atau usaha dalam rangka aktivitas penelitian untuk mengadakan hubungan dengan orang yang diteliti, metode untuk mencapai pengertian tentang masalah penelitian, racangan. ${ }^{13}$

Adapun pengertian fiqh secara etimologi adalah sebagai berikut:

1) Fiqh dalam bahasa arab علم و فهم yang artinya pengetahuan dan pemahaman. ${ }^{14}$

${ }^{10} \mathrm{Ibid}, \mathrm{hlm} .51$

${ }^{11} \mathrm{Ibid}, \mathrm{hlm} .53$

12Imam Suprayogo \& Tobroni, Metodologi Penelitian Sosial-Agama, (Bandung: Remaja Rosdakarya, 2003, Cet. II), 62.

${ }^{13}$ Kamus Besar Bahasa Indonesia, (Jakarta: Balai Pustaka , 1990), 193.

14 Ahmad Warson Munawwir, Kamus Al-Munawwir Arab-Indonesia Terlengkap, (Surabaya: Pustaka Progressif, 2002), 1067-1068. 
2) Menurut Atabik Ali dan A. Zuhdi Muhdlor dalam kamus AlBishri, fiqh dalam bahasa arab juga berarti علم و فهم yang artinya pengetahuan dan pemahaman. ${ }^{15}$

3) Pengertian fiqh dalam Kamus Ilmiah Populer Lengkap diartikan sebagai hukum ilmu hukum Islam. ${ }^{16}$

Berdasarkan beberapa pengertian di atas dapat disimpulkan bahwa pendekatan fiqh secara etimologi adalah cara atau aktivitas untuk mendekati Islam melalui ilmu hukum islam.

2. Pendekatan Secara Terminologi

Secara terminologi, pendekatan dapat diartikan sama dengan metodologi, yaitu sudut pandang/cara pandang dan memperlakukan sesuatu masalah yang dikaji. Makna metodologi juga mencakup berbagai teknik yang dilakukan untuk melakukan penelitian dan pengumpulan data. Dengan demikian, pendekatan atau metodologi bukan hanya diartikan sebagai sudut pandang atau cara melihat suatu permasalahan, melainkan juga mencakup pengertian metode-metode atau teknik-teknik penelitian yang sesuai dengan pendekatan tersebut. ${ }^{17}$

Sehingga pendekatan fiqih dapat memiliki urgensi :

a. Cara untuk memahami islam melalui Ilmu (fiqh).

1. Tujuannya adalah mengetahui hukum-hukum syariat bidang amaliyah (perbuatan nyata).

2. Dalil-dalil terperinci merupakan cara mengetahui hukum-hukum syara' amaliyah.

b. Cara untuk memahami Islam melalui hasil ilmu (produk ilmu fiqh).

1. Berupa kumpulan hukum-hukum syara'.

2. Ijtihad merupakan cara untuk memperolehnya.

\section{Strategi, Pendekatan dan Model-model Penelitian Fiqih}

Strategi pendekatan Fiqh dalam hukum Islam meliputi, Pertama, pendekatan tujuan syara', pertimbangan ini dimaksud untuk melihat bahwa istimbat hukum itu tidak hanya memperhatikan nas-nas Al quran dan hadist, melainkan yang substansi adalah memperhatikan tujuan-tujuannya. Artinya apa yang hendak dicapai dari nas itu. Strategi pendekatan tujuan syara' telah diperlihatkan oleh al-Buti yang menyatakan. ${ }^{18}$

“Dimana ditemukan (dicapai) kemaslahatan, maka disitulah syari'at (hukum) Allah. Oleh karena itu, tidak patut kita berbuatkaku pada nas-nas (teks al qur'an dan hadist) dan fatwa-fatwa terdahulu, dan tidak patut pula kita menutup diri dari perkembangan zaman dan kemaslahatan kekinian."

15 Atabik Ali dan A. Zuhdi Muhdlor, Kamus Kontemporer Arab-Indonesia "Al-Ashri", (Yogyakarta: Multi Karya Grafika, 1999), 1344.

16 Risa Agustin, Kamus Ilmiah Populer Lengkap, (Surabaya: Serba Jaya), 126.

17 Maman Kh, et al, Metodologi Penelitian Agama Teori dan Prektek, (Jakarta: Raja grafindo Persada, 2006), 94.

${ }_{18}$ Muhammad Sa'id Ramdan a-Buti, Dawabit al-maslahah fi asy-syari'ah al-Islamiyah, (Beirut: Muassasah ar-Risalah, 1986), 12 
Tujuan syara' menurut keterangan diatas adalah terciptanya kemaslahatan dalam kehidupan manusia. Kemaslahatan yang dimaksud adalah bersifat dinamis dan fleksibel. Artinya pertimbangan kemaslahatan di sesuaikan dengan perkembangan zaman. Belum tentu maslahat pada zaman dahulu juga maslahat pada zaman sekarang. Sehingga tujuan maslahat dalam hukum Islam itu adalah prinsip, dan keprinsipan maslahat sebagai tujuan hukum Islam ini telah disepakati oleh ahli hukum Islam. Menurut al-Buti terdapat lima kriteria dalam menentukan kemaslahatan, yaitu: Pertama, Memprioritaskan tujuan-tujuan syara' (syari'at), kedua, Tidak bertentangan dengan Al Qur'an, Ketiga, Tidak bertentangan dengan As Sunah, Keempat, tidak bertentangan dengan prinsip, kelima, memperhatikan kemaslahatan yang lebih penting (besar). ${ }^{19}$

Kedua, pertimbangan tatbiq melalui prinsip bidang/kewenangan (alasliyah). Perimbangan ini memprioritaskan pada akar masalah atau termasuk pada bidang apa masalah itu menempatkan dirinya, baik seluruh maupun sebagianya. Secara garis besar hukum syara' itu terpilih dalam dua kapling (bidang), yaitu bidang ibadah dan bidang mu'amalat. Untuk itulah ulama fiqih membangun suatu rumusan (kaidah) sebagai berikut:20 Dalam bidang ibadah "Suatu ibadah pada dasarnya batal hukumnya kecuali terdapat dalil yang memerintahnya". Kaidah dalam bidang muamalah "Suatu mu'amalat itu pada dasarnya sah hukumnya kecuali terdapat dalil yang mengharamkannya".

Ketiga, pertimbangan Tatbiq melalui pendekatan aktif-pasif. Pendekatan ini dilakukan untuk menyatakan apakah suatu keadaan (perbuatan, peraturan) itu sesuai dengan hukum Islam atau tidak, atau bagaimana hukum islam menghendaki sesuatu perbuatan/keadaan manusia. Pendekatan ini hanya melihat kepentingan dalil (nas) secara ideal. Seorang mujtahid menginterpretasi nas sehingga dari nas tersebut muncul suatu hukum yang mengatur manusia. Sebaliknya, jika pendekatan pasif dilakukan, yang muncul adalah apakah sesuatu keadaan/perbuatan itu bertentangan dengan hukum Islam atau tidak.

Kaidah tersebut menunjukkan ada dua strategi dalam menentukan hukum, yaitu yang pertama strategi deduktif dan induktif. Strategi deduktif bersifat aktif, karena nas yang menyatakan hukumnya, sedangkan strategi induktif bersifat pasif, sebab nas hanya bertindak sebagai pemberi legitimasi. Salah satu keistimewaan ajaran Islam adalah memiliki sistem hukum yang dinamis, karena dalil-dalilnya.baik mansuh (jelas dalam nas) maupun tidak mansuh (berdasarkan prinsip-prinsip ketuhanan dan kemanusiaan).

Untuk merealisasikan bangunan fiqih (sebagai ilmu) Mutawali menyarankan hal-hal sebagai berikut. ${ }^{21}$

\footnotetext{
${ }^{19} \mathrm{Ibid}, \mathrm{hlm} .142$

${ }^{20} \mathrm{Ibid}, \mathrm{hlm} .16$

${ }^{21}$ Abdul Wahab Afif, Figh, hlm.20-21
} 
a. Membuka pintu ijtihad lebar-lebar yang berarti menempatkan fiqih sebagai ilmu. Fiqih harus di posisikan dalam tataran akademik dengan tujuan berkembangnya diskursus keilmuan.

b. Membendung adanya anggapan bahwa proses tasyri' (penentuan hukum) telah selesai.

c. Memperjelas batas kewenangan dalam studi keagamaan (fiqiyah/furuqiyah) dan studi non keagamaan.

d. Bijaksana dalam menerima pendapat-pendapat ahli fiqih masa lampau (fuqaha dahulu).

\section{Fiqih Modern (Progresif) berdasarkan Maqasid Al Syariah perspektif Jaser} Auda

Jasser Auda berusaha menawarkan konsep fiqh modern berdasarkan Maqasid al Syariah. Islam adalah agama yang menjunjung tinggi nilai-nilai kemanusiaan dan memberikan solusi untuk kehidupan manusia agar selaras dan seimbang. Hal inilah yang berusaha diangkat oleh Jasser bagaimana sebuah konsep sistem dapat mengatur kehidupan umat Islam agar berjalan sesuai aturan dan memberi manfaat bagi manusia.

Dalam Maqasid al-Shari'ah as Philosophy of Law: A syistem Approach Jasser Auda mengartikan Maqasid pada empat arti, pertama, Hikmah dibalik suatu Hukum. Kedua, tujuan akhir yang baik yang hendak dicapai oleh Hukum. Ketiga, kelompok tujuan ilahiyah dan konsep Moral yang menjadi basis dari hukum. Keempat, Mashalih. Dalam konsep Maqasid yang ditawarkan oleh Jasser Auda, nilai dan Prinsip kemanusian menjadi pokok paling utama.

Jasser Auda mencoba mengkonstruk ulang konsep Maqashid Al Syariah lama yang bersifat protection and preservation menuju pada teori maqashid al syariah yang bersifat pada development and rights. Teori maqashid al syariah yang bersifat hirarkis mengalami perkembangan, terutama pada abad ke-20. Teori modern mengkritik klasifikasi kebutuhan (necessity) di atas dengan beberapa alasan berikut ini: a) Ruang lingkup teori maqashid al syariah meliputi seluruh hukum Islam, b) lebih bersifat individual; c) tidak memasukkan nilai-nilai yang paling universal dan pokok, seperti keadilan dan kebebasan (freedom); d) dideduksi dari kajian literature fighi, bukan mengacu pada sumber original. ${ }^{22}$

\section{Biografi Singkat Jaser Auda ${ }^{23}$}

Jaser Auda adalah Associate Professor di Qatar fakultas Studi Islam dengan fokus kajian kebijakan publik dalam program studi Islam.Jaser Auda adalah salah satu anggota pendiri persatuan ulama muslim

22 Galuh Nashrullah Kartika Mayangsari R dan H. Hasni Noor, Konsep Maqashid Al Syariah dalam menentukan Hukum Islam (Perspektif Al-Syatibi dan Jaser Auda), (Jurnal Al Iqhtishadiyah, 2014), 56.

${ }_{23}$ M. Arfan Mu'ammar, Abdul Wahid Hasan, dkk, Studi Islam Perspektif Insider/Outsider, (Yogyakarta: IRCiSoD, 2013), 389-391. 
Internasionalyang berbasis di Dublin, Selain itu Jaser Auda adalah anggota dewan akademik di Institut Internasional pemikiran Islam di London, Inggris dan masih banyak lagi jabatan yang di emban Jaser Auda.

Jaser Auda memperoleh gelar Ph.D dari Universitas of Wales (Inggris) pada konsentrasi Filsafat hukum Islam tahun 2008. Gelar Ph.D yang kedua diperoleh dari Universitas Waterloo (Kanada) dengan kajian analisis system tahun 2006.Master Fiqih diperoleh dari Universitas Islam Amarika, Michigan, pada tujuan Hukum Islam (Maqashid Al Syariah) tahun 2004.

Jaser Auda mendapat sembilan penghargaan bergengsi, 1), Global leader in Law Certificate, 2), Muslim Student Association of thr Cape Medal, 3). Internasional Center for moderation award, 4), Cairo Universiti Medal, 5), Innovation Award, 6), Province of Ontario, 7), Province of Saskatchewan, 8), Qur'an Memorization 1st Award, 9), Research Grand.

\section{Definisi Maqashid Al Syariah}

Secara terminologi, Makna Maqashid Al Syariah berkembang dari makna yang paling sederhana sampai pada makna yang holistik. Dikalangan ulama klasik belum ditemukan definisi yang konkrit dan komperehensif tentang Maqashid Al-Syariah. Ibnu Asyur mendefinisikan Maqashid Al Syariah adalah makna-makna dan hikmah-hikmah yang diperhatikan dan dipelihara oleh syar'i dalam setiap bentuk penemuan hukumnya. Para Ulama ushul sepakat bahwa Maqashid Al Syariah adalah tujuan-tujuan akhir yang harus terealisasi dengan diaplikasikanya syariat.

\section{Posisi Maqashid Al Syariah dalam Fiqih atau Hukum Islam}

Dalam sejarah perkembanganya, posisi Maqashid Al Syariah tidak begitu jelas dan terkesan dikesampingkan. Tiga unsur dalam satu sistem yang tidak terpisahkan dan berkembang dalam garis linier yang sama, Pertama, Ushul Al Fiqh menjadi metodologi yang harus diaplikasikan, Kedua, Qawaid Al Fiqh menjadi pondasi dasar bangunan fiqh yang ada, Ketiga, Maqasid Al Syariah yang menyumbangkan nilai-nilai dan spirit pada fiqih itu sendiri. ${ }^{24}$

Posisi Maqashid al Syariah kemudian mengalami perkembangan berikutnya pada masa Ibn As Syur, Ibn As Syur melihat perlunya Maqashid al syariah menjadi disiplin ilmu yang mandiri. Konsekuensinya adalah bahwa Maqashid Al Syariah tidak lagi hanya sebagian kumpulan konsepsi nilai yang membungkus Fiqih dan Ushul Fiqih, tetapi juga berevolusi menjadi sebuah pendekatan. Maqashid al syariah akhirnya menempati posisi sebtral dan fital dalam perkembangan hukum islam atau fiqih kontemporer.

\section{Pendekatan Teori Sistem pada teori Fiqih Perspektif Jaser Auda}

1. Kritisi Transidentalisasi Ijtihad

Jaser Auda secar tegas mengkritisi secara mayoritas ahli fiqih (fuqaha) yang menggambarkan bahwa hukum fiqih yang dihasilkan dari

\footnotetext{
${ }^{24} \mathrm{Ibid}, \mathrm{hlm}, 396-398$
} 
pemahaman, persepsi dan pengamatan mereka sebagai aturan Allah yang harus ditaati secara mutlak. Padahal Fiqih sendiri merupakan persepsi dan interpretasi seorang yang bersifat subyektif. Ayat-ayat Alquran adalah wahyu, tetapi interpretasi ulama berupa fiqih bukanlah wahyu. ${ }^{25}$

Jaser Auda mencontohkan dua hal hasil Ijtihad dalam fiqih yang sering dimasukkan dalam kategori pengetahuan wahyu, pertama, Ijma'(Konsensus), sebagian ulama fiqih menyebutnya sebagai dalil qath'i yang setara dengan nash (Al Qur'an dan Hadist). Dalam literatur fiqih tradisional banyak ditemukan bahwa Ijma' sering dijadikan klaim untuk menghakimi pendapat orang lain yang berbeda. Menurut Jaser Auda bahwa Ijma' (konsensus) bukanlah sumber hukum, tetapi hanya sebuah mekanisme atau sistem pembuatan kebijakan dengan melibatkan banyak pihak.

Kedua, tentang metode Qiyas (analogi), Ulama Fiqih menganggap bahwa metode qiyas adalah didukung dan diperintahkan oleh wahyu. Mereka berpendapat bahwa menganalogikan kasus hukum yang bersifat sekunder (yang tidak ada dalam nash) kepada kasus yang yang bersifat primer (yang ada dalam nash) adalah keputusan Allah.

\section{Pergeseran Pemahaman Fiqih}

1. Fiqih Tradisional.

Pada fiqih era tradisional, digambarkan bahwa peran fakih (para ahli agama) dianggap sederajat dengan syariah, dan seolah-olah sederajat pula dengan al-Qur'an dan Sunnah (prophetic tradition). Bahkan apa yang disebut prophetic tradition pun tidak atau belum dibedakan antar berbagai klasifikasi Hadis. Hadis-hadis misoginik, misalnya, dijadikan satu atau sederajat dengan hadis-hadis lain. ${ }^{26}$

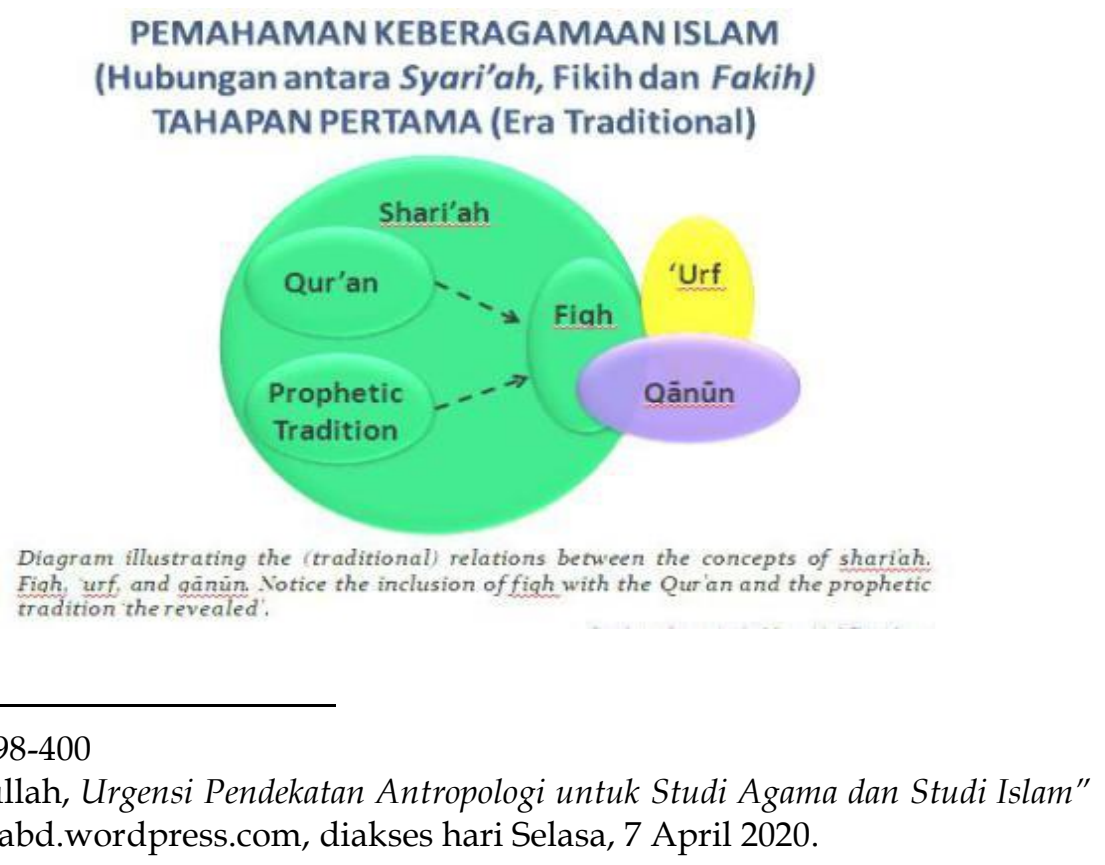

${ }^{25} \mathrm{Ibid}, \mathrm{hlm}, 398-400$

${ }^{26}$ Amin Abdullah, Urgensi Pendekatan Antropologi untuk Studi Agama dan Studi Islam" dalam http://aminabd.wordpress.com, diakses hari Selasa, 7 April 2020. 
2. Fiqih Era Modernitas

Pada fikih era modernitas, secara jelas sudah mulai dibedakan antara apa yang disebut revealed syariah, dengan al-Qur'an dan prophetic tradition di satu sisi dan peranfakih di sisi yang lain. Dalam wilayah prophetic tradition juga sudah dapat dipilah-pilah, mana hadis yang matannya dapat diterima dan mana yang kiranya tidak dapat diterima, sesuai dengan perkembangan pengetahuan dan literacy umat manusia. Fiqih (pemahaman keagamaan Islam dan prakteknya di lapangan oleh seorang fakih) pun sudah jelas di mana tempatnya. Dia sudah jelas berada di luar wilayah apa yang disebut dengan revealed syariah. ${ }^{27}$

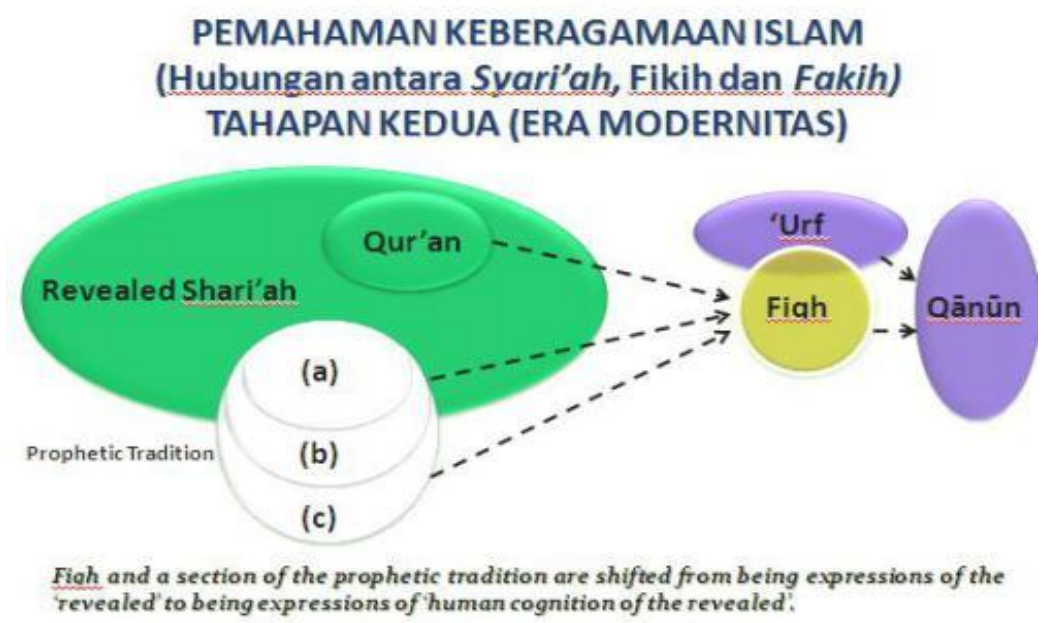

Dalam Gambar diatas, tradisi kenabian di bagi menjadi tiga kategori, Pertama, Nabi sebagai pembawa risalah kenabian. Disini nabi diposisikan sebagai sumber hukum, seperti bagaimana nabi melaksanakan shalat, puasa dan haji. Kedua, nabi sebagai seorang khalifah dan hakim (teks harus dipahami sesuai konteks yang dimaksud), posisi nabi disini masih dapat dijadikan rujukan hukum. Ketiga, Nabi sebagai manusia biasa, dalam hal ini tradisi kenabian tidak dapat dijadikan rujukan hukum, semisal nabi ketika memakai alat transportasi untu dalam bepergian, memakai gamis, sorban. Hal demikian harus di pahami sebagai bagian dari budaya lokal Arab. ${ }^{28}$

3. Fiqih Era Postmodernitas

Pada era postmodernitas, selain menggarisbawahi yang ada pada era modernitas, peran fakih jauh lebih jelas lagi dalam memahami agama. Yang baru di sini adalah bahwasanya pemahaman para ahli hukum agama (jurist), selain terinspirasi oleh al-Qur'an dan Sunnah, tetapi dia

\footnotetext{
27 Ibid

28 Ibid
} 
sesungguhnya sangat dipengaruhi oleh pandangan hidupnya sendiri, lingkungan yang ada disekitarnya, bahkan tingkat ilmu pengetahuan yang dimiliki umat manusia saat itu.

Faktor-faktor inilah yang ikut membentuk pandangan hidupnya (competent worldview). Sedang competent worldview- nya sangat dipengaruhi oleh tingkat penguasaan ilmu pengetahuan, baik pengetahuan alam, sosial, budaya dan humanitas kontemporer yang mengelilinginya. Artinya penafsiran teks-teks kitab suci dan juga sunnah sangat bersifat lokal.

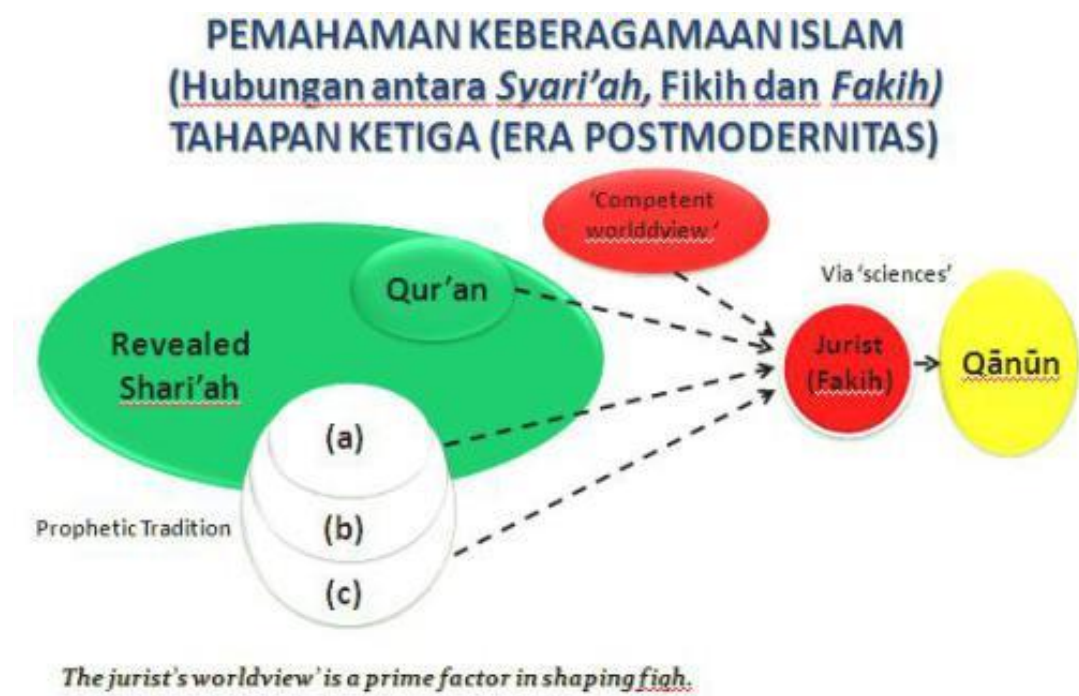

Dari ketiga gambar diatas, terlihat jelas perbedaan antara wahyu dan fiqih, konsekuensinya dalah tidak ada lagi opini fiqih yang benarbenar bisa diyakini kebenaranya secara mutlak. Fiqih tidak lain hanya sebagai pertimbangan atau cara pandang tentang otentitas (perwujudan dari keaslian), Implikasi Bahasa, Ijma' dan Qiyas. ${ }^{29}$

\section{KESIMPULAN}

Dalam rangka menjawab problematika Fiqih kontemporer dengan semangat bahwa Islam Shalihun likulli zaman wa makan, mempertimbangkan pendekatan Maqashid Al Syariah sebagai sistem hukum merupakan suatu keniscayaan. Sebab tantangan hukum Islam bukan saja terkait internal umat Islam itu sendiri, melainkan sejauh mana ajaran Islam mampu memberikan kontribusi pada peradaban modern.

Pendekatan Maqashid Al Syariah adalah pendekatan teori fiqih yang bersifat holistic (Kulliyun) dan tidak membatasi pada teks ataupun hukum parsialnya. Namun lebih mengacu pada prinsip-prinsip tujuan universal. Pendekatan menggunakan Maqashid al Syariah dapat mengatasi berbagai perbedaan, seperi gap antara sunni dan syiah ataupun gap politik umat Islam.

\footnotetext{
${ }^{29}$ M. Arfan Mu'ammar, Abdul Wahid Hasan, dkk, Op Cit, hlm, 403
} 
Dalam kajian Maqashid Al Syari'ah, pendekatan sistem dilakukan melalui beberapa langkah, yaitu :

1. Memvalidkan semua pengetahuan (multi pendekatan/ilmu)

2. Menggunakan Prinsip-prinsip Holistik.

3. Keberanian membuka diri dan melakukan pembaharuan.

4. Mengukur qat'i dan ta'arud dari sisi ketersediaan bukti pendukung dan penentuan skala prioritas berdasarkan kondisi sosial yang ada dan bukan dari verbalitas teks.

5. Menggunakan pertimbangan Maqashid sebagai pendekatan penetapan Fiqih atau Hukum Islam.

Pendekatan Maqashid hendaknya dijadikan sebagai tujuan pokok dari semua dasar metodologi linguistik dan rasional dalam Ijtihad, terlepas dari berbagai varian metode dan pendekatanya. Karena, merealisasikan Maqashid yang dijadikan sebagai sistem, pendekatanya akan dapat mencapai keterbukaan, pembaharuan, realistis dan fleksibel dalam sistem Fiqih. 


\section{DAFTAR PUSTAKA}

Abuddin Nata, Metodologi Studi Islam, (Jakarta: PT Raja Gafindo Persada, 2011).

Ahmad Warson Munawwir, Kamus Al-Munawwir Arab-Indonesia Terlengkap, (Surabaya: Pustaka Progressif, 2002).

Amir Nu'allim dan Yusdani, Konfigurasi Pemikiran Hukum Islam, (Yogyakarta: UII Press, 1999).

Atabik Ali dan A. Zuhdi Muhdlor, Kamus Kontemporer Arab-Indonesia "AlAshri", (Yogyakarta: Multi Karya Grafika, 1999).

Galuh Nashrullah Kartika Mayangsari R dan H. Hasni Noor, Konsep Maqashid Al Syariah dalam menentukan Hukum Islam (Perspektif Al-Syatibi dan Jaser Auda), Jurnal Al Iqhtishadiyah, 2014.

Imam Suprayogo \& Tobroni, Metodologi Penelitian Sosial-Agama, (Bandung: Remaja Rosdakarya, 2003).

Kamus Besar Bahasa Indonesia, (Jakarta: Balai Pustaka , 1990).

M. Arfan Mu'ammar, Abdul Wahid Hasan, dkk, Studi Islam Perspektif Insider/Outsider, (Yogyakarta: IRCiSoD, 2013).

Maman Kh, et al, Metodologi Penelitian Agama Teori dan Prektek, (Jakarta: Raja grafindo Persada, 2006).

Hermawan, Sulhani, Mohammed Arkoun, Kajian Ulang Pemikiran Islam, DINIKA Vol. 3 No. 1, January 2004.

Mohammad Daud Ali, Hukum Islam, pengantar ilmu hukum dan tata hukum Islam di Indonesia, (Jakarta: PT RajaGafindo Persada, 2011).

Risa Agustin, Kamus Ilmiah Populer Lengkap, (Surabaya: Serba Jaya).

Tim Penyusun Kamus, Pusat Pembinaan dan Pengembangan Bahasa, Kamus Besar Bahasa Indonesia, Edisi Kedua (Jakarta: Balai Pustaka, Cetakan Kesepuluh, 1999). 